\title{
PENGARUH KADAR PRO'TEIN PADA PAKAN BUATAN TERHADAP PERTUMBUHAN DAN KELANGSUNGAN HIDUP IKAN KAKAP PUTIH, Lates calcarifer Bloch
}

\author{
Utojo")
}

\begin{abstract}
ABSTRAK
Penelitian untuk melihat pengaruh kadar protein terhadap pertumbuhan dan kelangsungan hidup ikan kakap putih telah dilakukan di Teluk Bojo, Barru, Selat Sulawesi, selama 90 hari.

Wadah yang digunakan dalam penelitian berupa keramba jaring apung berukuran $1 \times 1 \times 1,25 \mathrm{~m}^{3}$ dengan mata jaring $1,5 \mathrm{~cm}$ sebanyak 9 keramba. Bobot awal ikan kakap putih 25,3-27,6 g/ekor, padat penebaran 10 ekor per keramba dan ransum diberikan 3 kali sehari sebanyak $5 \%$ dari bobot total ikan uji. Penelitian ini menggunakan rancangan acak lengkap dengan perlakuan kadar protein pakan yakni A (kadar protein $25 \%$ ), B (kadar protein 40\%), dan C (kadar protein 55\%), masing-masing dengan 3 ulangan.
\end{abstract}

Hasil penelitian menunjukkan bahwa semakin meningkat kadar protein, pengaruhnya makin efektif dan cepat terhadap pertumbuhan bobot mutlak dan kelangsungan hidup ikan. Pertumbuhan bobot mutlak dan kelangsungan hidup ikan tertinggi dengan konversi pakan terendah dicapai pada perlakuan kadar protein $40 \%$ yaitu $180,7 \mathrm{~g}$ dan 86,7\% serta 2,6. Pada saat kadar protein 55\% haju pertumbuhan mulai menurun. Hal ini disebabkan sudah melewati kadar protein pakan buatan yang optimal. Kadar protein pakan buatan berpengaruh nyata terhadap pertumbuhan bobot mutlak dan kelangsung. an hidup ikan.

\section{ABSTRACT: The Effect of Different Protein Content in Artificial Food on the Growth and Survival Rate of Seabases, Lates calcarifer Bloch, by: Utwo.}

An experiment to know the effect of feed protein content on the growth and survival rate of Seabass had been conducted at Teluk Bojo coastal waters, Barru, South Sulawesi, for 90 days.

This experiment was conducted in 9 floating net cages having the dimension of $1 \times 1 \times 1.25 \mathrm{~m}^{3}$ each and mesh size of $1.5 \mathrm{~cm}$. Initial weight of seabass was $25.3-27.6 \mathrm{~g}$ per individual with stocking densities of 10 fish per floating cage. Feeding was given at $5 \%$ of total body weight, three times per day.

This experiment was conducted using a completely randomized design. Three levels of protein content in diet i.e. A ( $25 \%$ protein), B ( $40 \%$ protein) and C (55\% protein) were tested with three replications for each treatment.

Results of this experiment showed that increase in protein content of feed produced substantial and better effect on the absolute weight and the survival rate of fish. Feed protein content of $40 \%$ gave highest absolute weight and survival rate and lowest feed conversion i.e. $180.7 \mathrm{~g}$ and $86.7 \%$ and 2.6 respectively. Increasing the protein content up to $55 \%$ produced lower growth rate.

KEYWORDS: Fisb culoure, artificial feed, survival rate, seabess

7) Peneliti pada Balai Penelitian Perikanan Pantai, Maros 


\section{PENDAHULUAN}

Ikan kakap putih, Lates calcarifer Bloch merupakan salah satu jenis ikan laut yang telah lama dikenal oleh petani tambak sebagai predator dan sekaligus merupakan hasil sampingan saat panen bandeng dan udang. Pada saat ini, ikan kakap putih sudah dikenal sebagai salah satu komoditi perikanan yang mempunyai nilai ekonomis penting baik sebagai ikan konsumsi maupun ekspor. Ikan ini mempunyai pasar internasional yang cukup baik terutama di Singapura, Australia, dan negara-negara Asia lainnya. Ikan kakap putih paling banyak dijumpai di restoran-restoran China dan sangat digemari oleh masyarakat luas karena mempunyai warna dan bentuk yang menarik, dagingnya tebal dan warnanya putih bersih, rasanya enak dan tidak banyak durinya, harganya berkisar Rp 3000,- sampai Rp 7000,- per kilogramnya (Sodikin, 1986; Ahmad et al., 1992). Kegiatan penangkapan sampai saat ini masih mendominasi produksi dan ekspor ikan kakap putih dari Indonesia karena kegiatan budidaya, dalam hal ini pembesaran, berjalan lambat. Apabila dilihat dari prospek budidayanya sangat baik karena dapat dibudidayakan di keramba jaring apung di laut, tambak, dan kolam (Grey, 1986).

Satu di antara kendala yang dihadapi dalam perkembangan usaha pembesaran ikan kakap putih adalah ketersediaan ikan rucah sebagai pakan utama. Ikan rucah yang bersifat musiman dan mudah menurun kualitasnya tidak mampu mengimbangi usaha budidaya ikan kakap putih yang memerlukan pakan berkualitas prima dalam jumlah mencukupi secara terus menerus. Pakan buatan kemudian dikembangkan untuk mengatasi masalah ketersediaan pakan bagi kegiatan budidaya ikan kakap putih secara berkesinambungan. Beberapa pertimbangan dari segi praktis dan ekonomis dalam pemilihan bahan untuk pakan buatan antara lain mempunyai nilai gizi atau kandungan protein relatif tinggi, mudah diperoleh, sangat mudah pengolahannya, tidak mengandung racun, harganya relatif murah, dan bukan merupakan makanan pokok manusia (Manik dan Djunaidah, 1980).

Upaya untuk mensubstitusi ikan rucah dengan pakan buatan dalam usaha budidaya ikan kakap putih telah dilakukan (Boonyaratpalin, 1989; Danakusumah dan Ismail, 1986). Namun penelitian mengenai kadar protein dalam pakan khusus untuk ikan kakap putih belum dilakukan secara intensif. Padahal pemberian pakan yang tepat dengan kadar protein yang sesuai selain dapat mempertinggi derajat efisiensi penggunaan pakan juga dapat memacu pertumbuhan dan kelangsungan hidup ikan yang dipelihara.

Berdasarkan latar belakang permasalahan tersebut, maka dilakukan penelitian dengan tujuan untuk mendapatkan pengaruh kadar protein dalam pakan buatan yang tepat terhadap pertumbuhan dan kelangsungan hidup ikan kakap putih. Hasil penelitian ini diharapkan dapat memberikan informasi mengenai ketersediaan pakan buatan yang cukup dan berkualitas baik untuk budidaya ikan kakap putih. 


\section{BAHAN DAN METODE}

Penelitian dilaksanakan selama 90 hari di Teluk Bojo, Kabupaten Barru, Sulawesi Selatan dengan menggunakan keramba jaring apung berukuran $1 \mathrm{x}$ $1 \times 1,25 \mathrm{~m}$ dengan mata jaring $1,5 \mathrm{~cm}$ sebanyak 9 buah. Keramba disusun sedemikian rupa dalam rakit berukuran $7 \times 7 \mathrm{~m}$ sebanyak 1 unit sehingga aliran air dalam tiap keramba jaring apung kira-kira sama.

Penelitian ini menggunakan rancangan acak lengkap dengan perlakuan kadar protein pakan, yaitu A (kadar protein $25 \%$ ), B (kadar protein $40 \%$ ), dan C (kadar protein 55\%), masing-masing dengan 3 ulangan. Untuk melihat pengaruh masing-masing perlakuan terhadap pertumbuhan dan kelangsungan hidup ikan dilakukan analisis sidik ragam, yang dilanjutkan dengan uji BNT 99\% dan $95 \%$.

Ikan uji berupa ikan kakap putih yang ditebar pada tiap keramba jaring apung berjumlah 10 ekor dengan bobot awal 25,3-27,6 g/ekor yang ditimbang setelah akhir adaptasi. Adaptasi lingkungan dan pakan dilakukan dalam keramba jaring apung yang ditandai dengan tidak lagi terjadi kematian dan semua ikan sudah memakan pakan buatan yang diberikan. Pakan (Table 1) diberikan dalam bentuk basah atau moist pellet dengan frekuensi 3 x sehari sebanyak $5 \%$ dari bobot total ikan uji yang ditimbang setiap 10 hari. Kandungan nutrisi dalam pakan dengan kadar protein berbeda disajikan pada Table 2. Peluang setiap ekor ikan untuk memperoleh pakan diusahakan sama dengan jalan penaburan pakan dalam bentuk lempengan pelet basah. Pakan dibuat setiap minggu dan disimpan dalam lemari es pada suhu sekitar $1^{\circ} \mathrm{C}$.

Table 1. Composition (\% dry matter) of feeds containing different levels of protein for seabass, Lates calcarifer Blocb

\begin{tabular}{lccc}
\hline \multirow{2}{*}{ Ingredient } & \multicolumn{3}{c}{ Protein level (\%) } \\
\cline { 2 - 4 } & 25 & 40 & 55 \\
\hline Fish meal & 10 & 25 & 40 \\
Rebon meal & 10 & 25 & 40 \\
Blood meal & 4 & 4 & 10 \\
Soybean meal & 5 & 10 & 2 \\
Corn meal & 2 & 2 & 2 \\
Rice bran & 65 & 30 & 2 \\
Squid oil & 1.2 & 1.2 & 1.2 \\
CMC & 1.5 & 1.5 & 1.5 \\
Vitamin mix & 0.8 & 0.8 & 0.8 \\
Mineral mix & 0.5 & 0.5 & 0.5 \\
\hline
\end{tabular}


Table 2. Nutrients content (\% dry matter) of artificial feeds fed to seabass, Lates calcarifer Bloch

\begin{tabular}{lccc}
\hline \multirow{1}{*}{ Ingredient } & \multicolumn{3}{c}{ Protein level (\%) } \\
\cline { 2 - 4 } & 25 & 40 & 55 \\
\hline Water & 1.37 & 1.38 & 1.29 \\
Protein & 26.35 & 41.20 & 55.03 \\
Fat & 12.26 & 13.43 & 11.25 \\
Ash & 7.75 & 9.24 & 9.12 \\
Crude fiber & 4.85 & 3.15 & 3.27 \\
Nitrogen free extracts & 47.42 & 31.60 & 20.04 \\
Energy (kcal/loo g) & 385.92 & 386.65 & 385.21 \\
C-P ratio & 14.65 & 9.38 & 7.00 \\
\hline
\end{tabular}

Ransum yang dianalisis antara lain kadar protein dengan metode ekstraksi Semi Micro Kjeldhal, lemak dengan metode ekstraksi Soxblet apparatus, kandungan energi menggunakan Bom Calorimeter, kadar abu dengan metode Muffle furnace dan ekstrak nitrogen bebas dengan metode Arithmetic difference serta serat kasar dengan metode Lepper modification (fiber apparatus) (SEAFDEC, 1978; Sudarmadji et al., 1984).

Pemantauan pertumbuhan bobot ikan dilakukan setiap 10 hari, sedangkan pertumbuhan bobot mutlak dan kelangsungan hidup ikan dihitung setelah penelitian berakhir. Bobot ikan uji ditimbang menggunakan Triple Beam Balance merk OHAUS kapasitas $2610 \mathrm{~g}$ dengan ketelitian 0,1 g.

Kondisi keramba jaring apung selama penelitian dipertahankan tetap baik dengan jalan membersihkan setiap kali sampling. Pertumbuhan bobot mutlak ikan dihitung berdasarkan rumus Royce (1972). Laju pertumbuhan harian ikan dihitung berdasarkan rumus Yamaguci (1978), sedangkan kelangsungan hidup ikan dihitung berdasarkan rumus Effendie (1979). Rasio konversi pakan (FCR) ditentukan berdasarkan rumus Sedgwick (1978). Untuk menghitung FCR diasumsikan bahwa semua pakan yang diberikan, dikonsumsi oleh ikan uji. Hal ini disebabkan pakan yang tidak sempat termakan dan lolos dari keramba sulit dikumpulkan.

Untuk mengetahui kelayakan habitat bagi kehidupan dan pertumbuhan ikan uji, maka dilakukan pengamatan terhadap peubah kualitas air setiap 7 hari yang meliputi salinitas dengan Atago Hand Refractometer, suhu dan oksigen terlarut dengan DO meter YSI 58, pH dengan $\mathrm{pH}$ meter vwv 252, karbondioksida, amonia, nitrit, nitrat, fosfat, besi (Fe), dan bahan organik total dengan spektrofotometer 21, kecerahan dengan secchidisk, kecepatan arus dengan 
current meter merk Izuzu, kedalaman dengan tali plastik berketelitian $10 \mathrm{~cm}$. Kelayakan habitat untuk kehidupan dan pertumbuhan ikan uji dianalisis secara deskriptif.

\section{HASIL DAN PEMBAHASAN}

Berdasarkan hasil penelitian selama 90 hari terlihat bahwa pertumbuhan bobot mutlak ikan kakap putih dipengaruhi secara nyata $(P<0,05)$ oleh kadar protein dalam pakan buatan. Makin meningkat kadar protein, pengaruhnya makin efektif terhadap pertumbuhan bobot mutlak ikan. Pertumbuhan bobot mutlak ikan yang tertinggi dicapai pada perlakuan pakan berkadar protein $40 \%$ yaitu $180,2 \mathrm{~g}$ dan yang terendah dicapai pada perlakuan pakan berkadar protein $25 \%$ yaitu $154,5 \mathrm{~g}$. Pertumbuhan bobot mutlak ikan yang diberi pakan berkadar protein $25 \%$ lebih rendah dari pada yang diberi pakan berkadar protein $40 \%$ dan $55 \%$. Tetapi pertumbuhan bobot mutlak ikan yang diberi pakan berkadar protein $40 \%$ lebih tinggi dari pada yang diberi pakan berkadar protein $55 \%$.

Laju pertumbuhan bobot harian ikan kakap putih juga dipengaruhi secara nyata $(\mathbf{P}<0,05)$ oleh kadar protein dalam pakan buatan. Laju pertumbuhan bobot harian ikan yang tertinggi dicapai pada perlakuan pakan berkadar protein $40 \%$ yaitu $1,73 \%$ dan yang terendah dicapai pada perlakuan pakan berkadar protein $55 \%$ yaitu $1,65 \%$. Ikan yang diberi pakan berkadar protein 40\% mempunyai laju pertumbuhan bobot harian lebih tinggi daripada yang diberi pakan berkadar protein $25 \%$ dan $55 \%$, tetapi ikan yang diberi pakan berkadar protein $55 \%$ mempunyai laju pertumbuhan bobot harian relatif lebih rendah daripada yang diberi pakan berkadar protein $25 \%$ (Table 3). Hal ini berarti bahwa kadar protein $40 \%$ dan lemak $13,43 \%$ dalam pakan buatan merupakan batas kadar protein yang optimal untuk pertumbuhan ikan kakap putih (Table 2). Hasil penelitian ini relatif sama dengan yang diperoleh dari penelitian Wong dan Chou (1989) dalam Boonyaratpalin (1991) melaporkan bahwa kadar protein yang optimal dalam pakan buatan untuk pertumbuhan ikan kakap putih berkisar $40-45 \%$ dengan kadar lemak $12 \%$. Tetapi hasil penelitian ini lebih baik dari pada hasil penelitian Sakaras et al. (1989 dalam Boonyaratpalin, 1991) melaporkan bahwa pakan berkadar protein $45 \%$ dan lemak $18 \%$ memberikan pertumbuhan ikan kakap putih yang paling tinggi. Pada saat pemberian pakan berkadar protein $55 \%$ mulai menurunkan laju pertumbuhan bobot ikan. Hal ini disebabkan respon kadar protein pakan sudah melewati batas optimal dalam memacu pertumbuhan bobot ikan. Sedangkan pertumbuhan bobot mutlak ikan yang terendah dicapai pada perlakuan pakan berkadar protein $25 \%$. Hal ini diduga ikan kakap putih tidak dapat menggunakan karbohidrat yang tingkat kadarnya dalam pakan tinggi karena terdapatnya serat kasar yang sukar dicerna (Table 2). 
Table 3. Weight gain, survival rate and feed conversion ratio of seabass, Lates calcarifer Bloch, reared in floating net cage after 90 days.

\begin{tabular}{lrrrr}
\hline \multicolumn{2}{c}{ Variables } & \multicolumn{3}{c}{ Treatment (protein content) } \\
\cline { 3 - 5 } & & $A(25 \%)$ & $B(40 \%)$ & $C(55 \%)$ \\
\hline Initial weight & (g/ind.) & 27.6 & 26.5 & 25.3 \\
Final weight & $(g /$ ind.) & 182.1 & 206.7 & 193.2 \\
Weight gain & (g/ind.) & $154.5^{a}$ & $180.2^{b}$ & $167.9^{c}$ \\
Survival rate & $(\%)$ & $66.7^{a}$ & $86.7^{b}$ & $80.0^{b}$ \\
Daily growtb rate & $(\%)$ & $1.65^{a}$ & $1.73^{b}$ & $1.64^{a}$ \\
Food conversion & & 3.2 & 2.6 & 3.1 \\
\hline
\end{tabular}

Note: Mean value in lines with the same superscript indicates no signifiant difference $(P>0.05)$.

Ikan kakap putih termasuk ikan karnivora yang mencerna protein relatif lebih besar jumlahnya dibandingkan dengan ikan omnivora dan herbivora yang digunakan sebagai sumber energi terutama untuk pertumbuhannya (Zonneveld et al., 1991). Komposisi pakan berkadar protein $25 \%$ terdiri dari bahan-bahan yang didominasi dedak halus umumnya banyak mengandung serat kasar sehingga dapat mempengaruhi daya cerna dan daya serap zat-zat makanan bagi ikan (Djajasewaka dan Djajadiredja, 1980). Pakan yang berkadar protein $40 \%$ menunjukkan persentase protein bahan hewani relatif berimbang dengan protein nabati sehingga ketersediaan beberapa asam amino yang saling bersubstitusi lebih banyak dari pada pakan berkadar protein $25 \%$ dan $55 \%$. Pakan berkadar protein $40 \%$ mempunyai kandungan energi yang lebih tinggi dari pada pakan berkadar protein 25 dan 55\% (Table 1 dan Table 2). Energi ini sangat diperlukan bagi aktivitas ikan. Selain itu, kadar protein dan lemak yang tinggi pada pakan berprotein $40 \%$ juga bermanfaat bagi pembentukan jaringan ikan. Menurut Hardy (1991) perbandingan antara karbohidrat dan protein dalam pakan sangat mempengaruhi pemanfaatan protein untuk pembentukan jaringan. Apabila karbohidrat dalam pakan tidak mencukupi sebagai sumber energi, maka ikan terutama ikan buas seperti ikan kakap putih akan memanfaatkan protein tidak hanya untuk pembentukan jaringan tetapi juga sebagai sumber energi untuk gerak. Menurut New (1987), pada pakan berkadar protein rendah sparring effect dari karbohidrat tidak sebaik pada pakan berkadar protein tinggi karena karbohidrat bukan merupakan sumber energi utama bagi ikan buas.

Kadar lemak dalam pakan juga ikut menentukan dalam pemanfaatan protein sebagai sumber energi untuk pembentukan jaringan dan aktivitas, karena lemak mempunyai nilai energi yang tinggi dan mengandung vitamin yang larut di dalamnya. Dalam penelitian ini kandungan nutrisi terutama 
lemak tertinggi terkandung pada pakan berkadar protein $40 \%$ yaitu $13,43 \%$. Kadar lemak ini termasuk dalam tingkat optimal bagi pakan ikan kakap putih yang berkisar 13-18\% (Boonyaratpalin, 1989). Sumber energi bagi ikan kakap putih lebih banyak berasal dari lemak dan protein dari pada berasal dari karbohidrat (Cowey dan Sargent, 1972).

Energi sebesar 386,7 kkal ME/100 g pakan terbukti memadai untuk mendukung pemanfaatan pakan yang mengandung $40 \%$ protein secara lebih efisien. Hasil tersebut selaras dengan hasil yang diperoleh dari penelitian Garling (1975 dalam NRC, 1977) yaitu kandungan energi antara 209-407 kkal ME/100 g pakan menghasilkan pertumbuhan Channel catfish terbaik pada pemberian pakan berkadar protein tinggi.

Pemanfaatan protein untuk membentuk jaringan selain dipengaruhi oleh kandungan energi dalam pakan, juga dipengaruhi kadar asam amino yang paling rendah ketersediaannya (New, 1987). Tepung kedelai yang ditambahkan pada pakan yang diberikan ikan kakap putih merupakan satu diantara sumber asam amino utama untuk mensubstitusi ketersediaan asam amino yang paling rendah. Karena itu peningkatan kadar protein dalam pakan diikuti peningkatan laju pertumbuhan dan perbaikan rasio konversi pakan.

Pada pemberian pakan berkadar protein $40 \%$, substitusi tepung ikan dan rebon dengan tepung kedelai sampai $10 \%$ diduga telah mampu meningkatkan ketersediaan beberapa asam amino karena nilai cerna tepung kedelai yang lebih tinggi, sedangkan kekurangan metionin masih dapat diimbangi oleh tepung ikan dan rebon (Table 1). Shimeno et al. (1992) menyatakan kandungan tepung kedelai sampai dengan $20 \%$ dalam pakan ikan secara ekonomis menguntungkan karena mempunyai tingkat efisiensi pakan yang tinggi dan pertumbuhan kedelai dapat mensubstitusi tepung ikan sampai dengan $20 \%$ dalam pakan ikan ekor kuning, sementara tepung kedelai merupakan sumber protein yang baik. Akiyama et al. (1991) menyarankan kadar tepung kedelai dalam pakan ikan berkisar 10 sampai $25 \%$. Penggabungan dua atau lebih sumber protein dalam pakan dapat memacu pertumbuhan ikan, selama penggabungan tersebut saling melengkapi kekurangan dari masing-masing sumber (Alava dan Lim, 1983).

Ikan kakap putih yang diberi pakan berkadar protein $40 \%$ pada saat ditebar sampai hari ke-50 memperlihatkan pola laju pertumbuhan yang naik turun (Figure 1). Ketidak stabilan laju pertumbuhan ikan tersebut disebabkan adanya kepekaan perubahan kondisi lingkungan hidupnya dalam menerima pakan. Setelah hari ke-50 sampai pada akhir penelitian, ikan kakap putih yang diberi pakan berkadar protein $40 \%$ memperlihatkan pola laju pertumbuhan lebih tinggi dari pada yang diberi pakan berkadar protein $55 \%$. Hal ini disebabkan pakan berkadar protein $40 \%$ pada hari ke-50 nampak mulai efektif pengaruhnya terhadap laju pertumbuhan ikan. Sedangkan ikan kakap putih yang diberi pakan berkadar protein $25 \%$ pada saat ditebar sampai akhir penelitian mem- 
perlihatkan pola laju pertumbuhan yang lebih rendah dari pada pakan berkadar protein $40 \%$ dan $55 \%$. Hal ini disebabkan pakan berkadar protein $25 \%$ mempunyai nilai nutrisi yang sangat rendah dan kurang sesuai untuk memacu pertumbuhan ikan karnivora.

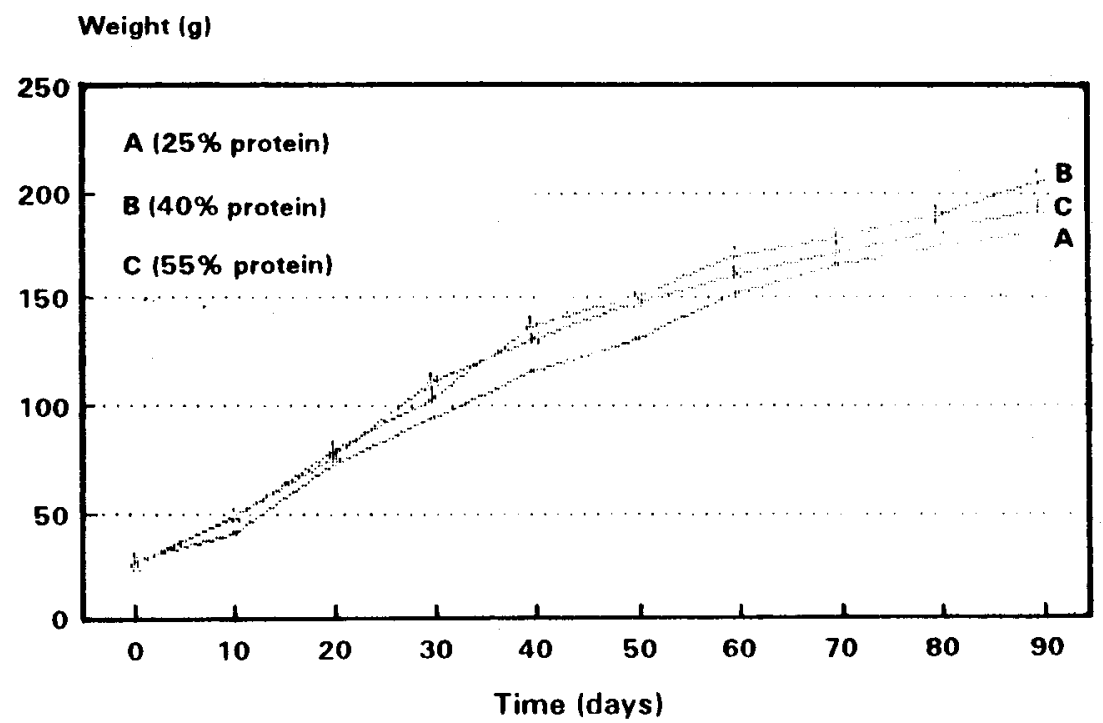

Figure 1. Weight gain ( $g$ ) of seabass fed with three different levels of protein content in floating net cage during 90 days culture

Kelangsungan hidup ikan kakap putih yang dihasilkan oleh pakan berkadar protein $40 \%$ lebih tinggi dan berpengaruh tidak nyata dengan pakan berkadar protein $55 \%$, tetapi pakan berkadar protein $25 \%$ lebih rendah dan berpengaruh nyata dengan pakan berkadar protein $40 \%$ dan $55 \%$ (Table 3). Tampaknya penambahan kadar protein pakan $40 \%$ cukup efektif untuk pemeliharaan tubuh ikan dalam menunjang kelangsungan hidupnya, tetapi pada penambahan kadar protein pakan 55\% justru menurunkan kelangsungan hidupnya. Pada pemberian pakan berkadar protein $25 \%$ belum tercapai kondisi optimal untuk meningkatkan kelangsungan hidup ikan dibandingkan dengan pakan berkadar protein $40 \%$ dan $55 \%$. Cowey dan Sargent (1972) menyatakan bahwa protein dalam pakan digunakan oleh ikan untuk pemeliharaan tubuh, pertumbuhan jaringan atau penambahan protein tubuh, dan penggantian jaringan yang rusak. Hal ini sangat dipengaruhi oleh jumlah dan jenis asam amino esensial, kadar protein yang dibutuhkan, kandungan energi pakan, dan faktor fisiologis ikan itu sendiri. 
Perbedaan pertumbuhan bobot mutlak ikan kakap putih selaras dengan perbedaan rasio konversi pakan pada setiap perlakuan (Table 3). Konversi pakan yang terendah dihasilkan oleh pakan berkadar protein $40 \%$ yaitu 2,6 dan konversi pakan yang tertinggi dihasilkan oleh pakan berkadar protein $25 \%$ yaitu 3,2. Semakin rendah konversi pakan semakin baik karena sedikit jumlah pakan yang dihabiskan untuk menghasilkan bobot tertentu ikan. Menurut Akiyama dan Chwang (1989), faktor yang mempengaruhi konversi pakan adalah kualitas dan pengelolaan pakan selama pemeliharaan seperti pendugaan kelangsungan hidup, dosis dan waktu pemberian pakan. Faktor lain yang ikut berpengaruh antara lain jenis dan ukuran pakan, umur dan ukuran ikan, sifat genetis, bau, dan daya tahan pakan di dalam air.

Besaran peubah kualitas air harian selama penelitian seperti yang disajikan pada Table 4 menunjukkan kualitas air masih berada pada rentang yang layak bagi kehidupan dan pertumbuhan ikan kakap putih. Menurut Ahmad et al. (1991) kisaran mutu air yang optimal bagi kehidupan dan pertumbuhan ikan kakap putih antara lain oksigen terlarut 4-8 mg/1, pH 6,5-8,0, salinitas 16-30 ppt, nitrat $0,9-3,2 \mathrm{mg} / 1$, fosfat $0,2-0,5 \mathrm{mg} / 1$, dan suhu $25-32^{\circ} \mathrm{C}$.

Table 4. Water quality variables during the experiment

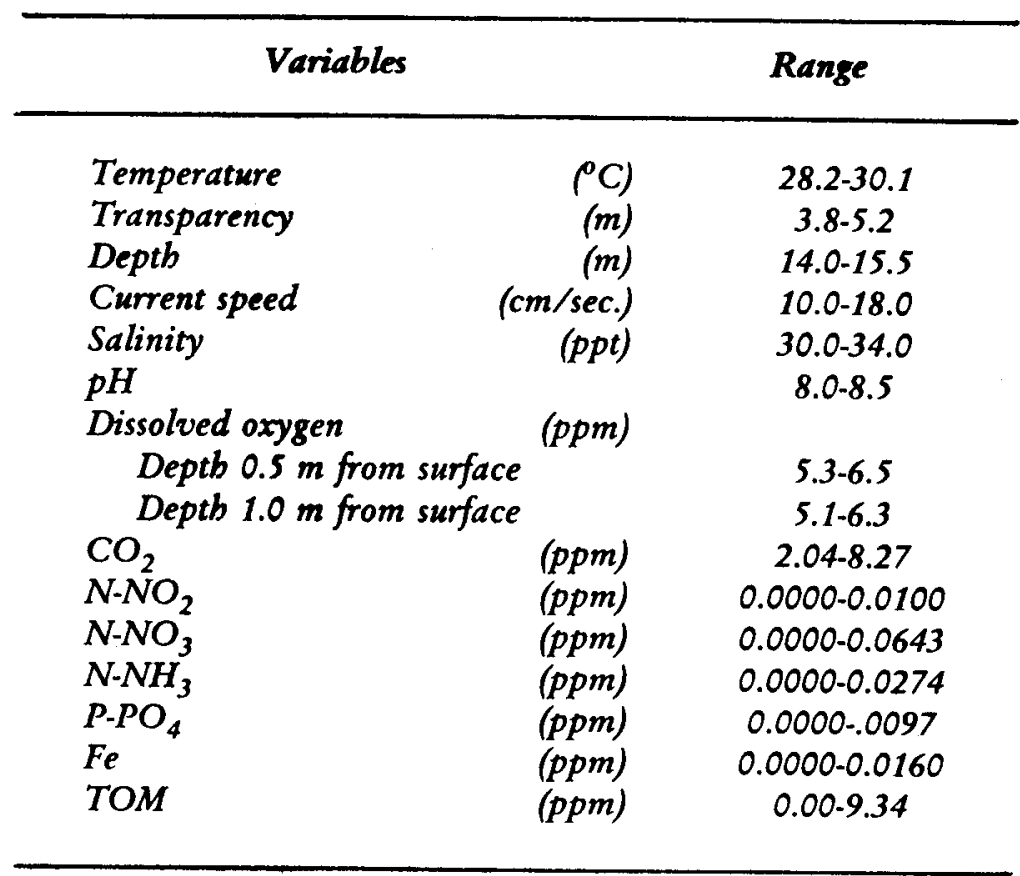




\section{KESIMPULAN DAN SARAN}

Kadar protein pakan $40 \%$ mempunyai pengaruh yang terbaik terhadap laju pertumbuhan harian, pertumbuhan bobot mutlak, kelangsungan hidup dan konversi pakan ikan kakap putih.

Penelitian mengenai substitusi tepung ikan sebagai komponen termahal dalam pakan buatan dengan sumber protein lain yang lebih murah perlu dilakukan untuk menekan biaya produksi.

\section{DAFTAR PUSTAKA}

Ahmad, T., S. Diani dan R. Purba. 1992. Status pembenihan ikan laut di Indonesia, p. 87-97. Dalam Prosiding Lokakarya Ilmiah Potensi Sumberdaya Perikanan Maluku, Ambon. Balai Penelitian Perikanan Budidaya Pantai Maros.

Ahmad, T., P.T. Imanto, Muchari, A. Basyarie, P. Sunyoto, B. Slamet, Mayunar, R. Purba, S. Diani, S. Redjeki, S.A. Pranowo, dan S. Murtiningsih. 1991. Operasional Pembesaran Ikan Kerapu dalam Keramba Jaring Apung. Balai Penelitian Perikanan Budidaya Pantai Maros, p. 48.

Akiyama, D. 1991. The use of soybean products and other plant protein supplements in aquaculture feeds. ASA Technical Bulletin Vol. AQ 27. 18p.

,W.G. Dominy, and A.D. Law rence. 1991. Penaeid shrimp nutrition for the commercial feed industry. Revised $2^{\text {nd }}$ edition. American Soybean Association, $34 \mathrm{p}$.

, and N.L.M. Chwang. 1989. Shrimp feed requirements and feed management, p. 75-82. In D.M. Akiyama (ed.) Proceedings of the Southeast Asia Shrimp Farm Management Workshop. Philippines, Indonesia, Thailand. July 26 - Agust 11, 1989.

Alava, V.R. and C. Lim. 1983. The quantitative dietary protein requirement of Penaeus monodon juvenile in controlled environment. Aquaculture 30:53-61.

Boonyaratpalin, M. 1989. Seabass culture and nutrition. In D.M. Akiyama (ed.). Proceedings of the Peoples Republic of China Aquaculture and Feed Workshop. p. 43-91.

- 1991. Nutritional studies on seabass (Lates calcarifer), p. 33-41. In SS. De Silva (ed.). Fish Nutrition Research in Asia. Proceedings of the Fourth Asian Fish Nutrition Workshop Asian Fish Soc. Spec. Publ. Asian Fisheries Society, Manila, Philippines.

Cowey, C.B. and J.R. Sargent. 1972. Fish Nutrition Advances in Marine Biology. Academic Press, London and New-York, (10):383-492. 
Danakusumah, E. and A. Ismail. 1986. Culture seabass (Lates calarifer) in earthen brackishwater pond. In J.W. Copland and D.L. Grey (eds.). Management of Wild and Cultured Seabass/Barramundi (Lates calcarifer). ACIAR Proceedings. p. 156-157.

Djajasewaka, H. dan R. Djajadiredja. 1980. Pengaruh makanan buatan dengan kandungan serat kasar berbeda terhadap pertumbuhan ikan mas. Buletin Penelitian Perikanan. Badan Penelitian dan Pengembangan Pertanian, Pusat Penelitian dan Pengembangan Perikanan, 1(1):55-57.

Effendie, M.I. 1979. Metode Biologi Perikanan. Cetakan pertama. Penerbit Yayasan Dewi Sri, Bogor. 112 p.

Grey, D.L. 1986. An overview of Lates calcarifer in Australia and Asia, In J.W. Copland and D.L. Grey (eds.). Management of Wild and Culture Seabass/ Barramundi (Lates calcarifer). ACIAR Proceedings. p. 15-21.

Hardy, R.W. 1991. Feed manufacturing and use. Takeda Chemical Industries, Ltd, Japan. 48 p.

Manik, R. dan I.S. Djunaidah. 1980. Pedoman Pembenihan Udang Penaeid. Direktorat Jenderal Perikanan, Departemen Pertanian, Jakarta. p. 83-94.

National Research Council (NRC). 1977. Nutrient requirement of warm water fishes. National Academy of Sciences, Washington, DC., USA. 63 p.

New, M.B. 1987. Feed and feeding of fish and shrimp: a manual on the preparation and presentation of compound feeds for shrimp and fish in aquaculture. UNDP, FAO, Rome. p. 1-27.

Royce, W.F. 1972. Introduction to the Fishery Sciences. Academic Press. Inc. New-York. San-Francisco, London.

Sedgwick, R.W. 1979. Influence of dietary protein and energy on growth, food consumption and food conversion efficiency in Penaeus merguiensis de Man. Aquaculture. 16:7-30.

Shimeno, S., H. Hosokawa, M. Kumon, T. Masumoto and M. Ukawa. 1992. Inclusion of defatted soybean meal in diet for fingerling yellowtail. ASA Technical Bull. Vol. AQ. 6:1.

Sodikin, D. 1986. Riview of the seabass (Lates calcarifer) fishery in Indonesia. In J.W. Copland and D.L. Grey(eds.). Management of Wild and Cultured Seabass/Barramundi (Lates calcarifer). ACIAR Proceedings. p. 57-58.

South East Asian Fisheries Development Center (SEAFDEC), 1978. Laboratory Manual for the Analysis of Water, Feeds and Feed Ingredients. Aquaculture Department, Southeast Asian Fisheries Development Center, Tigbauan, Iloilo, Philippines. 65 p. 
Utojo

Sudarmadji, S., B. Haryono dan Suhardi. 1984. Prosedur Analisis Untuk Bahan Makanan dan Pertanian. Penerbit Liberty, Yogyakarta. p. 49-90.

Yamaguchi, M. 1978. Practical Method and Premiere Knowledge Culture of Red Seabream, Kosheshakoseikoku, Japan.

Zonneveld, N., E.A. Huisman dan J.H. Boon. 1991. Prinsip Prinsip Budidaya Ikan. Penerbit PT Gramedia Pustaka Utama, Anggota IKAPI, Jakarta, hal. 72-102. 